\title{
THE RESEARCH SITE VRCHSLATINA - AN EXPERIMENTAL DESIGN AND THE MAIN AIMS
}

\author{
Bohdan Konôpka ${ }^{1,2}$, Jozef PajtíK ${ }^{1,2}$, Vladimír ŠebeŇ ${ }^{1}$, Michal BošEl'A ${ }^{1}$, \\ František MÁliš ${ }^{1}$, Tibor Priwitzer ${ }^{1}$, PAVEl PaVlenda ${ }^{1}$ \\ ${ }^{I}$ National Forest Centre - Forest Research Institute Zvolen, T. G. Masaryka 22, SK - 96092 Zvolen, \\ e-mail: bkonopka@nlcsk.org \\ ${ }^{2}$ Czech University of Life Sciences Prague, Faculty of Forestry and Wood Sciences, Kamýcká 129, \\ CZ - 16521 Praha 6 - Suchdol
}

Konôpka, B., Pajtík, J., Šebeñ, V., Bošela, M., Máliš, F., Priwitzer, T., Pavlenda, P., 2013: The Research Site Vrchslatina - an experimental design and the main aims. Lesnícky časopis - Forestry Journal, 59(3): 203-213, 2013, 5 fig., tab. 2, ref. 15, ISSN 0323-1046. Discussion paper.

The research site "Vrchslatina" was established in the spring of 2009 with the aim of studying production processes and the structure of net primary productivity in young forest stands. The beech and spruce stands grown at the site were selected because they originated from natural regeneration and are nearly of the same age. In 2009, we established 5 research plots in each stand with the aim of measuring basic tree characteristics. Moreover, we excavated entire trees to construct allometric relations for the specific tree compartments. In the consecutive years (2010, 2011 and 2012), we also included grass communities dominated by Calamagrostis epigejos in our studies. Besides studying production processes of all tree compartments (i.e. for trees: foliages, branches, stem, coarse and fine roots, for grasses and herbs: below- and above-ground parts), we monitored several atmospheric characteristics, followed by soil characteristics and eventually added a measurement of soil respiration. The results indicated that forest stands (even though they were in their initial growth stages) sequestrated much more carbon than the grass communities. Moreover, we proved the considerable influence of climatic conditions (especially the sum of precipitation) in the particular years for net primary productivity.

Keywords: European beech, Norway spruce, grass community, net primary productivity, biomass standing stock

\section{Introduction and objectives}

Climate change and its inherent phenomena influence the natural environment including the conditions for forest ecosystem existence and productivity. At the same time, forests constitute the most important terrestrial ecosystem contributing to the global carbon cycle and to carbon sequestration (Dixon et al., 1994). Forest ecosystems are not just passive objects of climate change; nonetheless through several feedbacks they are able to mitigate this phenomenon (JANSSENS et al., 2005). Hence, research interest in recent years has been intensively focused on interactions between climate and forest ecosystems, especially the role of forest stands for carbon sequestration. The weakness of previous studies lies in that most of them focused on the determination of biomass stocks only in the aboveground parts of forest stands, i.e. in the stem, branches and sometimes also in assimilation apparatus. Similarly, in Slovakia, belowground biomass of forest trees has received only scant attention (e.g. KonôPKA et al., 2011). Even worldwide, the available data on tree biomass production is often related only to perennial woody tissues, ignoring foli- 
age and especially fine roots. HeLmisAari et al. (2002) indicate that from the biochemical cycling point of view, these two biomass pools are of utmost importance as they constitute the main organs of material and energy exchange. Unlike the stem, branches and coarse roots, the ephemeral biomass pools have a much faster turnover (foliages of deciduous trees - once a year, fine roots obviously between once to twice a year).

Net Primary Productivity (NPP) is a concept widely used in ecology to describe the total amount of energy (or carbon) accumulated by the photosynthesis of green plants, minus the energy used for respiration of primary producers (e.g. Li et al., 2002). NPP describes the biomass (or carbon) accumulated in the stems, branches, roots and foliage during a given period of time, usually one year. The most difficult components of forest NPP to quantify are fine roots (often defined as less than 2 $\mathrm{mm}$ in diameter (LuSTER and FinLAY, 2006). Fine roots are commonly negligible in terms of standing biomass, but are crucial for the quantification of NPP and in the assessment of the forest carbon cycle. HelmisaARI et al. (2002) found that in pine plantations fine roots contributed to between $2-15 \%$ of biomass, depending on the age of each forest stand. The contribution of fine roots to the NPP, however, was around half of the total quantity.

The aforementioned facts motivated us to study issues related to the structure of forest standing stock and NPP including all trees' above- and below-ground tree compartments. We commenced the work on these issues in 2005 within the research project "Quantification of the biomass of forest stands in the first age class" (APVT-27-023504). Our experience from the project suggested that for understanding inter-species differences in biomass production and allocation, various forest types grown under the same conditions (identical sites) should be studied. Thus, we established a temporary research object representing European beech and Norway spruce, both originating from natural regeneration. The principal condition was not only the same site but also comparable stand age (in 2009 individual beech and spruce trees manifested ages between 10 and 14 years, the mean age in both species was 12 years; see also ŠEBEŇ et al., 2013).

In the early stage of the growing season of 2009, the research object "Vrchslatina" was established. The principal objectives of the studies were:

- to construct site-specific allometric relations for tree compartments of beech and spruce,

- to analyze the impact of growing conditions on allometric relations,

- to determine NPP and its structure by measuring increments of individual compartments (foliages, branches, stems, coarse and fine roots),

- to quantify the impact of seasonal weather variations on NPP in beech and spruce stands. Later (since 2010), we set up another objective: to focus on stan- ding stock and productivity in grass communities occurring at the same site.

\section{Environmental conditions and properties of the stands}

In fact, finding young stands of beech and spruce originating from natural regeneration with very similar ages grown on the same site was not an easy task. We had operative assistance from forest service employees of the Sihla and Polana Forest Districts. Nearly all our requirements relating to environmental conditions and stand properties were matched on a locality which was situated a few hundred meters northeast from the village of Vrchslatina. Here, we established our temporary research object in the spring 2009.

The locality of the "Vrchslatina" research object is situated in the central part of Slovakia on the border of the districts Detva and Brezno, a land area belonging to the town of Hriňová (Figure 1). It is located at an altitude between 950 and $970 \mathrm{~m}$ above sea level (coordinates: between $48^{\circ} 38^{\prime \prime}$ '50' and $48^{\circ} 38^{\prime \prime}$ ' $59^{\prime} \mathrm{N}, 19^{\circ} 36^{\prime \prime} 00^{\prime}$ and $\left.19^{\circ} 36^{\prime \prime} 14^{\prime} \mathrm{E}\right)$, at a size of 8.43 ha, situated approximately $10 \mathrm{~km}$ north-east from Hriňová. The area is owned by the Forests of the Slovak Republic, Forest Enterprise in Kriváň, Polana Forest District.

The site belongs to the fifth (fir-beech) altitudinal forest zone. The area represents optimum ecological conditions for the existence of beech and is the southernmost region of natural occurrence of spruce in Slovakia. This fact is important for defining our research mission. In general- under climate change, beech with its ecological demands is a more perspective tree species than spruce (see e.g. LiNDNER et al., 2010). Most probably, the localization, elevation and site conditions are becoming progressively more unsuitable for spruce. Thus, replacing spruce stands with beech ones would be advisable for these conditions. On the other hand, such tree species conversion might bring about serious consequences for carbon sequestration and cycling in forests (KoNôPKA et al., 2013a).

The site is situated in the geomorphological unit Veporské vrchy Mts., subunit Sihlianska plateau that is composed mainly of porphyric granodiorites, biotite tonalites and granites. Cambisols were developed from this parent material. The soil properties at the research site are favourable. The soil is classified as Cambisol $(\mathrm{Hu}-$ mic, Eutric). The textural class of the fine earth fraction is qualified as sandy loam. Though the rock fragments content is relatively high (about $30-35$ percent volume in the whole assessed soil profile), almost all of the rock fragments are in the fraction fine gravel $(0.2-0.6 \mathrm{~cm})$ and so this does not have a negative influence on the soil properties. The soil reaction is only slightly acid. The values of $\mathrm{pH}$ measured in hydrosupension were between 5.1 and 5.4 and values measured in $\mathrm{CaCl}_{2}$ extract were between 4.3 and 4.6 (gently decreasing towards the soil 


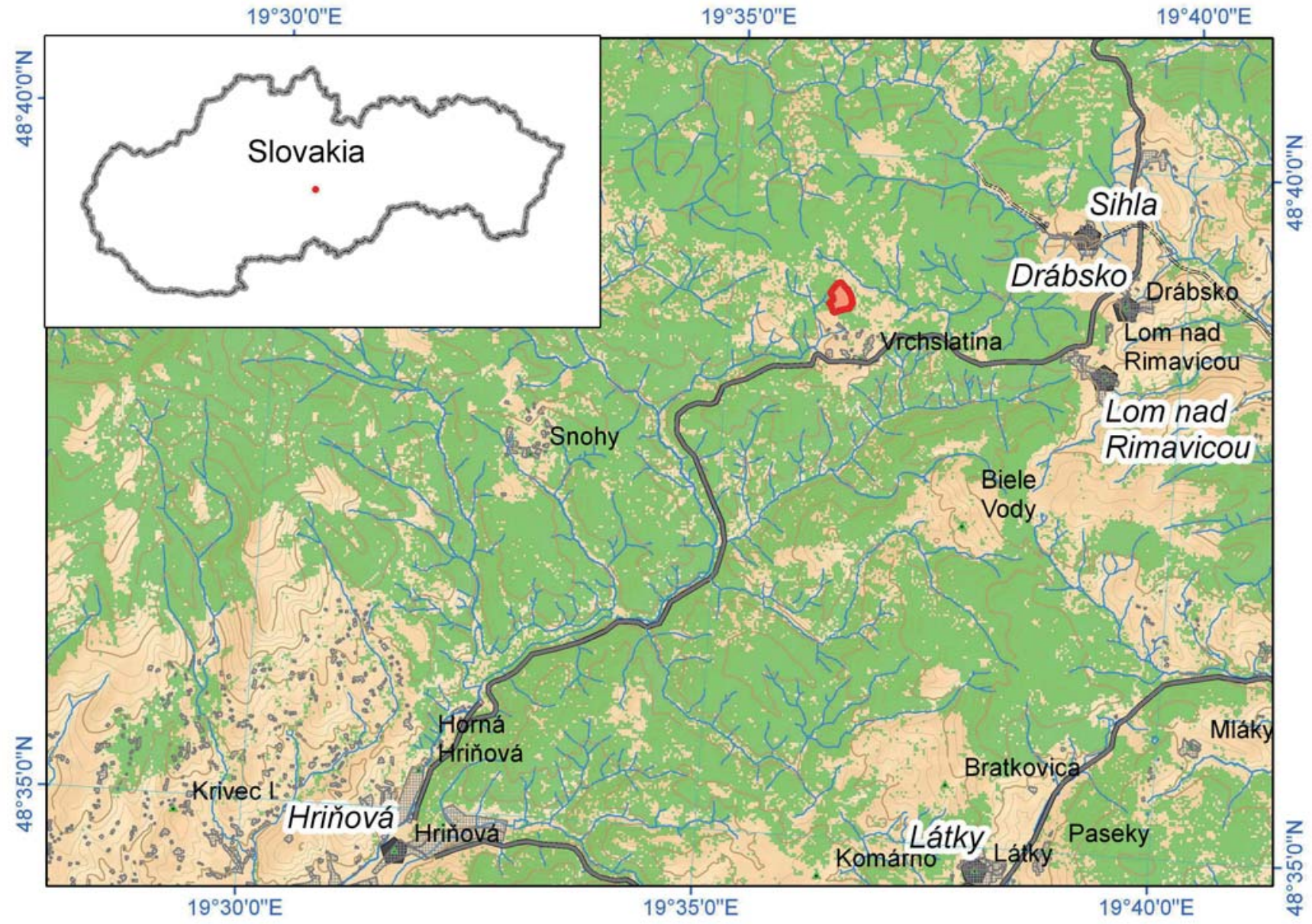

Fig. 1. Localization of the Vrchslatina research site (red polygon)

surface). The content of soil organic carbon (SOC) is high (above average for forest soils in Slovakia). In A horizon the SOC content is almost $7 \%$ and even at the depth of 50 to $100 \mathrm{~cm}$ it is about $1 \%$. It also has a positive effect on soil structure and denstity. The total carbon storage of soil to a depth of $100 \mathrm{~cm}$ was calculated as 197 t.ha $^{-1}$. The $\mathrm{C} / \mathrm{N}$ ratio values indicated a good quality of soil organic matter.

As for meteorological conditions in the years of our observations, rather different patterns of air temperature and sum of precipitation were recorded (Figure 2). The highest value of annual air temperature was in 2012 $\left(6.9^{\circ} \mathrm{C}\right)$, the lowest one in $2010\left(5.6^{\circ} \mathrm{C}\right)$. On the other hand, the highest annual sum of precipitations was in $2010(1527 \mathrm{~mm})$ and the lowest in $2011(683 \mathrm{~mm})$. Thus, inter-annual variability was more evident in sums of precipitation than in mean air temperatures. In fact, 2009 was typical with a lack of precipitations during almost the entire growing season. The years 2011 and 2012 manifested drought episodes in the end of the growing seasons, 2010 was rainy from May to the end of the year. All observed years were evidently warmer than a long-term (i.e. 1961 - 1990) annual temperature average $\left(4.7^{\circ} \mathrm{C}\right)$.
The measurements focused on forest complexes composed exclusively of beech or spruce, near even-age stands originating from natural regeneration. Both forest complexes rose prevailingly in 1995 and 1996 under sparse mother stands. The old trees were harvested in the following $2-3$ years. An aerial photograph shows that only a few old single trees existed on the site in 2002 and those trees were outside of the plots with our later measurements. Then, an aerial photograph snapped in 2006 showed no old trees remaining in the site (Figure 3).

The target complexes of beech and spruce were directly neighboring; however, the forest did not cover the entire area. Some open areas among forest complexes were colonized by grass communities dominated by bush grass (Calamagrostis epigejos). In 2009, five circular plots in beech and five in spruce were established and all trees inside the plots were labeled and basic tree characteristics were measured (Table 1). Besides the young stands, we studied diameter increments of older beech and spruce trees, specifically 20 individuals of each. Their mean heights were $10.3 \mathrm{~m}$ and $10.5 \mathrm{~m}$, mean diameters at breast height were $15.5 \mathrm{~cm}$ and $15.3 \mathrm{~cm}$ for beech and spruce respectively. Moreover, in 2010, our 

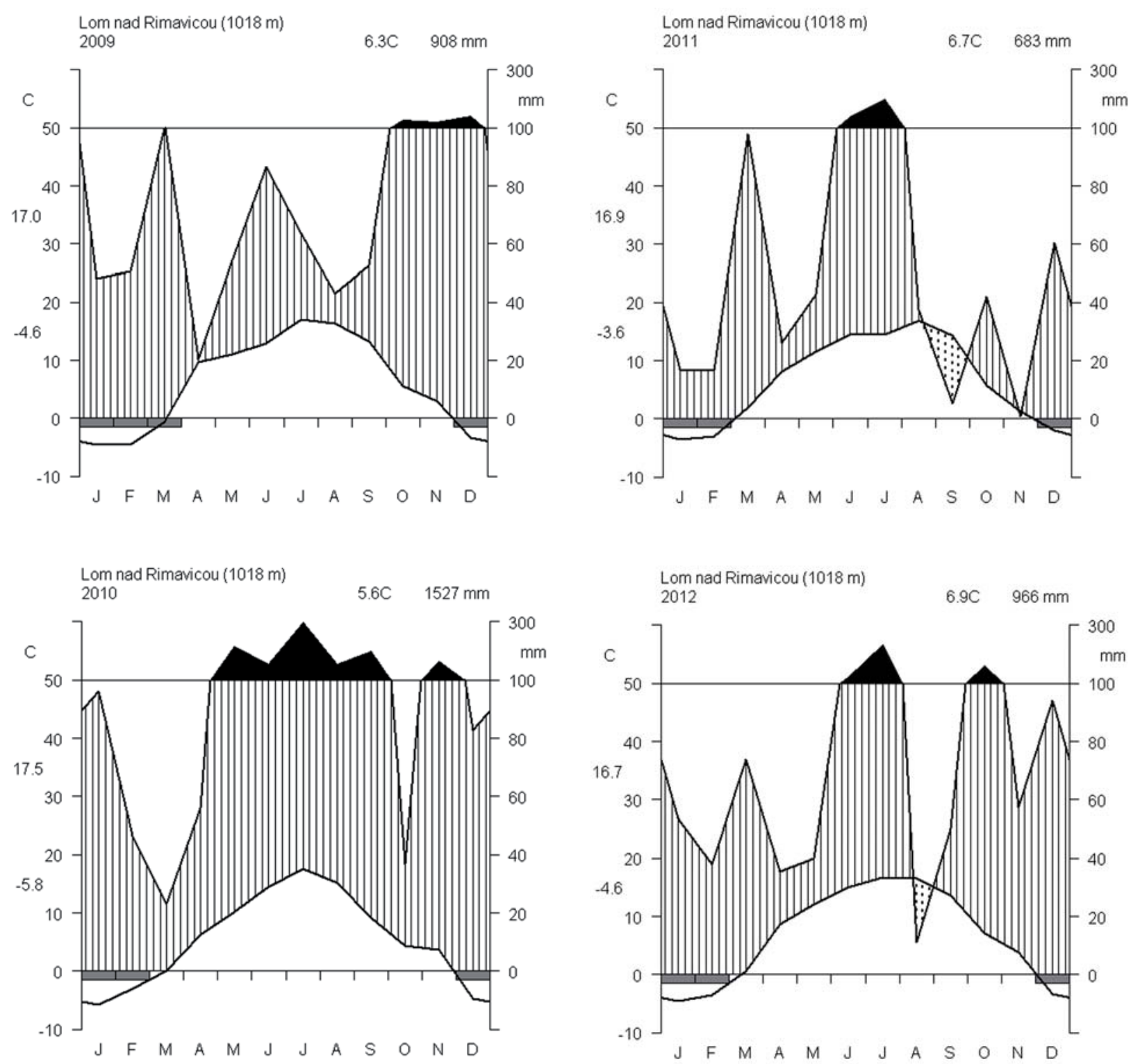

Fig. 2. Monthly mean temperatures and sum of precipitations in 2009 - 2012 (data from the Lom nad Rimavicou Meteorological Station)
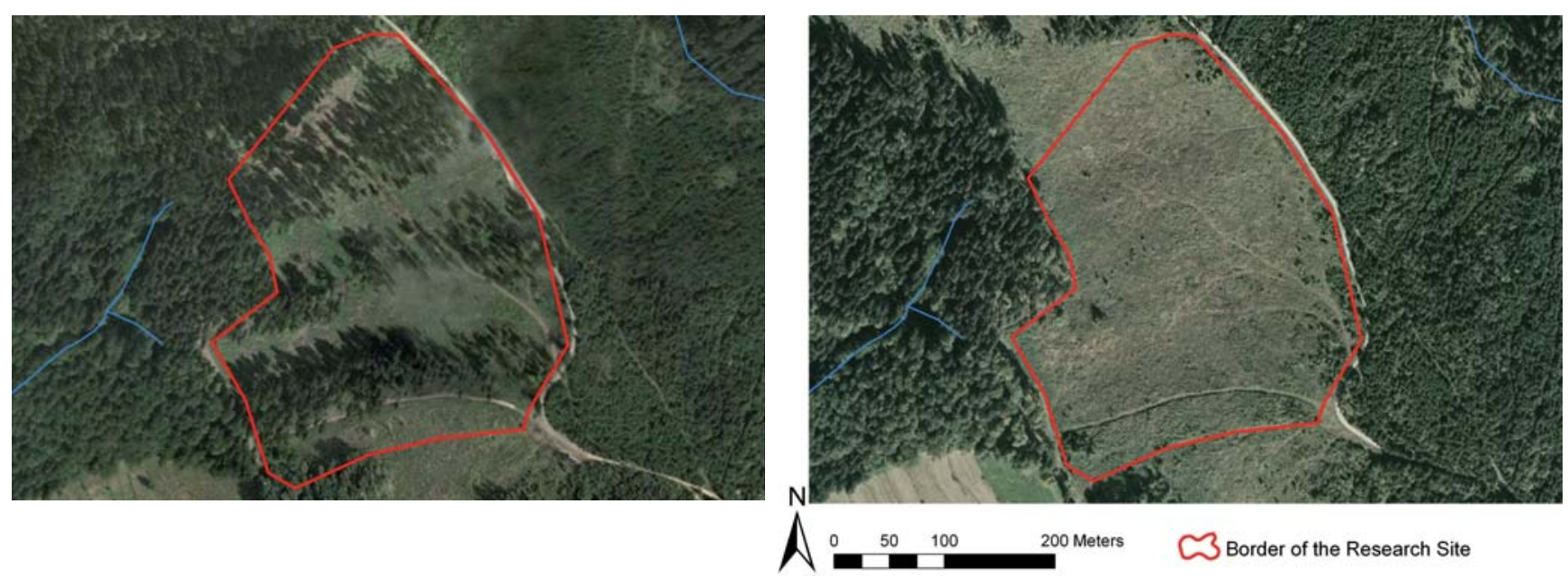

Fig. 3. Arial photos of the Vrchslatina research site in 2002 (left plate) and 2006 (right plate) 
Table 1. Basic characteristics of the beech and spruce plots as recorded in the spring 2009

\begin{tabular}{|c|c|c|c|c|c|c|}
\hline $\begin{array}{c}\text { Species and } \\
\text { plot number }\end{array}$ & $\begin{array}{c}\text { Size of plot } \\
{\left[\mathbf{m}^{2}\right]}\end{array}$ & $\begin{array}{c}\text { Number } \\
\text { of trees }\end{array}$ & $\begin{array}{c}\text { Range of tree } \\
\text { diameters [mm] }\end{array}$ & $\begin{array}{c}\text { Mean tree } \\
\text { diameter [mm] }\end{array}$ & $\begin{array}{c}\text { Range of tree } \\
\text { heights [cm] }\end{array}$ & $\begin{array}{c}\text { Mean tree } \\
\text { height [cm] }\end{array}$ \\
\hline Beech 1 & 3.14 & 39 & $6.7-39.0$ & 21.1 & $70-320$ & 251.2 \\
Beech 2 & 2.01 & 39 & $7.5-31.3$ & 18.7 & $60-290$ & 227.0 \\
Beech 3 & 3.14 & 54 & $5.2-27.4$ & 16.2 & $37-230$ & 184.2 \\
Beech 4 & 3.14 & 47 & $7.7-42.0$ & 22.2 & $60-300$ & 236.8 \\
Beech 5 & 3.14 & 43 & $9.3-37.9$ & 19.1 & $50-375$ & 292.5 \\
\hline Spruce 1 & 3.14 & 38 & $5.2-69.3$ & 22,0 & $50-259$ & 186.3 \\
Spruce 2 & 2.01 & 41 & $4.5-42.7$ & 16.8 & $38-185$ & 144.0 \\
Spruce 3 & 1.54 & 44 & $3.2-36.6$ & 13.8 & $20-245$ & 141.9 \\
Spruce 4 & 3.14 & 49 & $5.6-47.0$ & 19.5 & $40-290$ & 197.7 \\
Spruce 5 & 1.54 & 30 & $5.0-35.2$ & 18.3 & $35-260$ & 195.9 \\
\hline
\end{tabular}

Table 2. Basic characteristics of the grass plots as recorded in the summer 2010

\begin{tabular}{|c|c|c|c|c|c|}
\hline Plot number & $\begin{array}{c}\text { Size of plot } \\
{\left[\mathbf{m}^{2}\right]}\end{array}$ & $\begin{array}{c}\text { Mean height of } \\
\text { bushgrass stalk } \\
{[\mathbf{m m}]}\end{array}$ & $\begin{array}{c}\text { Number of } \\
\text { bushgrass stalk } \\
\text { [pieces] }\end{array}$ & $\begin{array}{c}\text { Bushgrass } \\
\text { contribution to } \\
\text { plant aboveground } \\
\text { biomass [\%] }\end{array}$ & $\begin{array}{c}\text { Number } \\
\text { of plant species }\end{array}$ \\
\hline 1 & 0.25 & 118.5 & 12 & 59.5 & 8 \\
2 & 0.25 & 106.8 & 12 & 90.4 & 6 \\
4 & 0.25 & 90.1 & 13 & 79.1 & 5 \\
5 & 0.25 & 95.3 & 8 & 67.9 & 5 \\
\end{tabular}

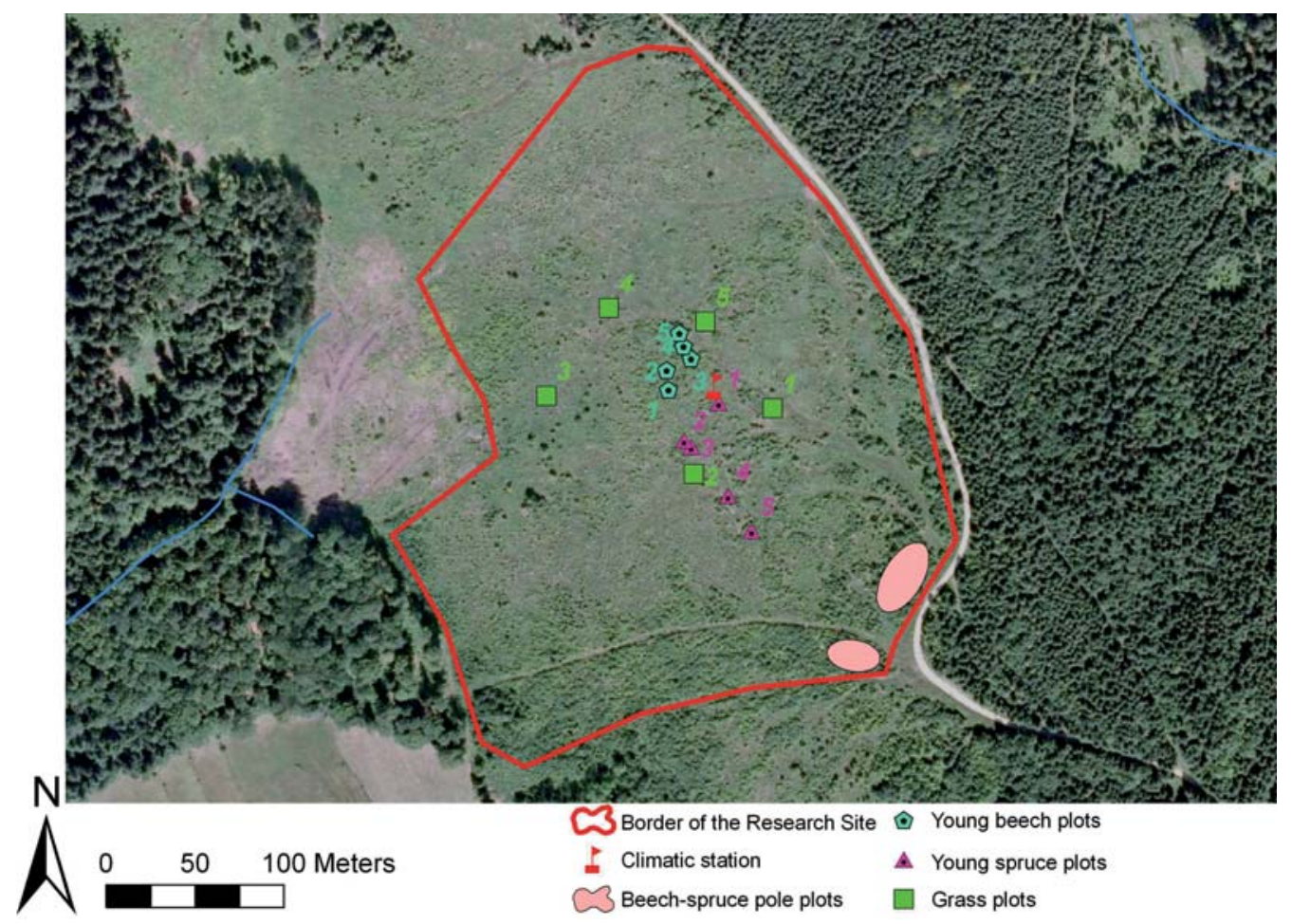

Fig. 4. Arial photo of the Vrchslatina research site 2009 with indication of the plots

studies were extended to measurements on grass stands with Calamagrostis epigejos as a dominant species. Hence, we established five square shaped plots with the area $36 \mathrm{~m}^{2}$ where subplots for detailed measurements and sampling of $0.5 \times 0.5 \mathrm{~m}$ were plotted (Table 2$)$. The positions of all research plots are shown in the Figure 4. 
At the beginning of the experiment (first year), our activity was part of the project "Research on effective utilization of environmental, economic and social potency of the forests in Slovakia" (ZúBRIK et al., 2009). Since 2010, the research expenses were covered from the project "Comparative studies on allocation of net primary productivity in beech and spruce stands" (APVV-026810; see KonÔPKA et al., 2010).

\section{Research activities in $2009-2012$ and experimental design}

As already mentioned, the research object was established in the spring of 2009. In this year, research activities were exclusively focused on beech and spruce stands. Studies on grass communities were started in the spring of 2010. Since we have performed a variety of research activities and measurements, we describe them by the particular years. The following description concerns only the most important types of measurements, fringe and supporting observations are omitted. Some other details on research activities are shown in the other papers of this special issue (BoŠELA et al., 2013; KonÔPKA et al., 2013b; Máliš et al., 2013; PAJTíK et al., 2013; PriwitZer et al., 2013; ŠEBEŇ et al., 2013).

Early in the spring of 2009, we established 5 plots in the young beech stands and another 5 plots in the young spruce stands. The size of the plots in the beech stands was chosen purposefully to cover at least 30 trees. Specifically, the radius of the plots in the beech was between 0.8 and $1.0 \mathrm{~m}$, between 39 and 54 trees. The radius of the plots in the spruce was between 0.7 and $1.0 \mathrm{~m}$, the number of trees between 30 and 49. The trees on the plots were measured for height, stem diameter at ground level $\left(\mathrm{d}_{0}\right)$ and diameter $130 \mathrm{~cm}$ from ground level $\left(\mathrm{d}_{1.3}\right)$. Moreover, trees were categorized into 4 bio-sociological classes (dominant: trees with heights evidently over the main level of the canopy, co-dominant: trees with heights circa equaling the main level of the canopy, subdominant: trees with heights slightly under the main level of the canopy, and suppressed: trees with heights evidently under the main level of the canopy). Three litter collectors (plastic containers with upper square openings 27 $\times 27 \mathrm{~cm}$ ) were placed on each plot to find the seasonal dynamics of litter fall and its yearly amount. At the same time, we installed mini meteo-stations to record global radiation, air temperature, air moisture, and precipitations in the open area (grassland). Sensors for continuous measurements of soil moisture and temperature (at a depth of $10 \mathrm{~cm}$ ) were placed on each plot.

At the end of April 2009, we sampled 30 soil cores (three cores in the vicinity of each plot). The soil cores were taken by a metal auger (inner diameter of $7 \mathrm{~cm}$ ) up to the soil depth of $50 \mathrm{~cm}$. The soil column was split for 5 subsamples (soil depths 0 - 10, $10-20,20-30,30-40$ and $40-50 \mathrm{~cm}$ ), transferred to the laboratory and deep frozen up until the time of further processing. Live and dead fine roots of beech and spruce were separated and washed, oven-dried and weighed. This way, the quantity (standing stock) of beech and spruce fine roots was estimated and expressed on a unit area basis. In parallel with soil coring, ingrowth bags (cylinder-like plastic nets with mesh $2 \times$ $2 \mathrm{~mm}, 30 \mathrm{~cm}$ long, filled with sand) were installed in the young stands. Specifically, six pieces on each plot. Half of the bags was harvested at the end of the 2009 growing season and the other half at the end of 2010. The sand from the bags was processed in a similar way as described for the soil cores. This experiment served to estimate annual fine root production in both beech and spruce.

During the first half of the growing season 2009, we observed seasonal oscillation of the height increments in the young beech and spruce. Before the measurements, we selected 40 individuals of beech and 40 of spruce (in both trees, 10 pieces for every bio-sociological position). Height increments of current terminal shoots were measured by ruler approximately twice a week exclusively during the current year shoot growth (in May and June for beech; in June, July, and August for spruce; see also KonÔPKA et al., 2013a).

Besides the young beech and spruce stands, our measurements also focused on the older stand (pole stage) composed of 20 individual beech and 20 individual spruce trees. The trees were used for seasonal dynamics of diameter increment by using mechanical dendrometers (metal belts operated by a spring with a micrometer scale). We had to use these larger trees because the dendrometers are applicable only for stems with diameters over $10 \mathrm{~cm}$. However, seasonal dynamics of diameter increments on the older trees is supposed to be similar to that in young individuals (transfer of knowledge to our young beech and spruce stands).

In August 2009, we performed whole-tree samplings of young spruces (the trees were selected from outside of the circular plots). Precisely 80 trees were excavated. Their heights and diameters were measured, and then their tree bodies were separated for these compartments: coarse roots (those with a diameter over $2 \mathrm{~mm}$ ), stem, branches and needles. As for branches and needles two groups were made up: those born in the current year (2009), the others (2008 and older). The trees were selected to cover proportionally the entire height intervals found in the stand. The tree compartments were transported to the laboratory, oven dried to a constant mass and weight. Finally, allometric equations for each compartment were constructed by using diameter and/ or height as independent variables.

In September 2009, we sampled foliages from both beech and spruce stands. The samples were taken from 40 trees (10 of each bio-sociological class; all were selected outside of the circular plots) and from three levels of the crowns: upper, middle and lower. The samples were scanned, dried and weighed. This work indicated variability in foliage size, foliage weight and specific 
leaf area (area per weight unit) between trees of different sociological status and between assimilatory organs from different levels of crowns. Specific leaf areas served for conversion from foliage biomass to foliage area on both tree and stand levels.

In 2010, we did almost the same work as conducted in the previous year. The main difference was in the whole-tree sampling: we sampled 80 beech trees instead of spruce. The samples were processed in the same way as the spruces were. In addition, we cut 40 spruces in the autumn and sampled only the current shoots to estimate the yearly needle production. New experiments were started in grass stands, which were characteristic of a dominance of Calamagrostis epigejos. We established 5 plots with an area of $36 \mathrm{~m}^{2}$. Each plot was used for the further study of above- and below-ground standing stock and production of the grass community. To establish quantity of aboveground biomass, sampling on subsamples, sized $0.5 \times 0.5 \mathrm{~m}$ was performed. Here, all plants were cut, dried and weighed. The aboveground sampling was done three times a year - in the early spring, the middle and the end of growing season. To estimate standing stock and production of belowground biomass, two methods - soil cores and in-growth bags were utilized. In-growth bags were installed in early spring and harvested (always 15 pieces) in the middle and the end of the 2010 growing season and one set at the end of the 2011 growing season. In early November 2010, we installed 15 transparent tubes (one piece by each plot, i.e. 5 for every ecosystem) to scan the fine roots of the plants. The tubes were $100 \mathrm{~cm}$ long with an outer diameter of $7.0 \mathrm{~cm}$. Since cca $80 \mathrm{~cm}$ long sections of the tubes were embedded under the soil at an angle of $45^{\circ}$, soil profiles up to the depth of $40 \mathrm{~cm}$ could be observed. The first scanning (using a root scanner CI-600, see also: http://www.cid-inc.com/root-image/ci-600.php) was preformed after 1.5 years.

The year 2011 was as usual with the same field work as done in 2010. Additional work was related to the measurement of coordinates for five circular plots in both young beech and spruce stands (see example in the Figure 5). Here, the position of each tree was expressed by the angle and distance from the plot's centre point. In this year, we did not conduct whole-tree sampling; just 40 spruces were cut for an estimation of the current year's needle production. Also, we separately cut each needle set (i.e. according to its year of birth) to record age structure of foliage on spruces. We measured height increments of stems and length increments of branches. To measure the diameter increments of the stem base, discs were cut from the sample individuals and yearly changes were measured for the entire life of the trees.

In 2012, all the measurements were taken more or less as in the previous years. This year, we started to scan roots in the transparent tubes. The first scanning was done at the end of April; further sessions were at the end of every month till the end of October. Our field work was extended to soil respiration measurements. The measurements were done in 45 plastic collars (with an inner diameter of $10 \mathrm{~cm}$ ), 3 pieces on each plot, i.e. 15

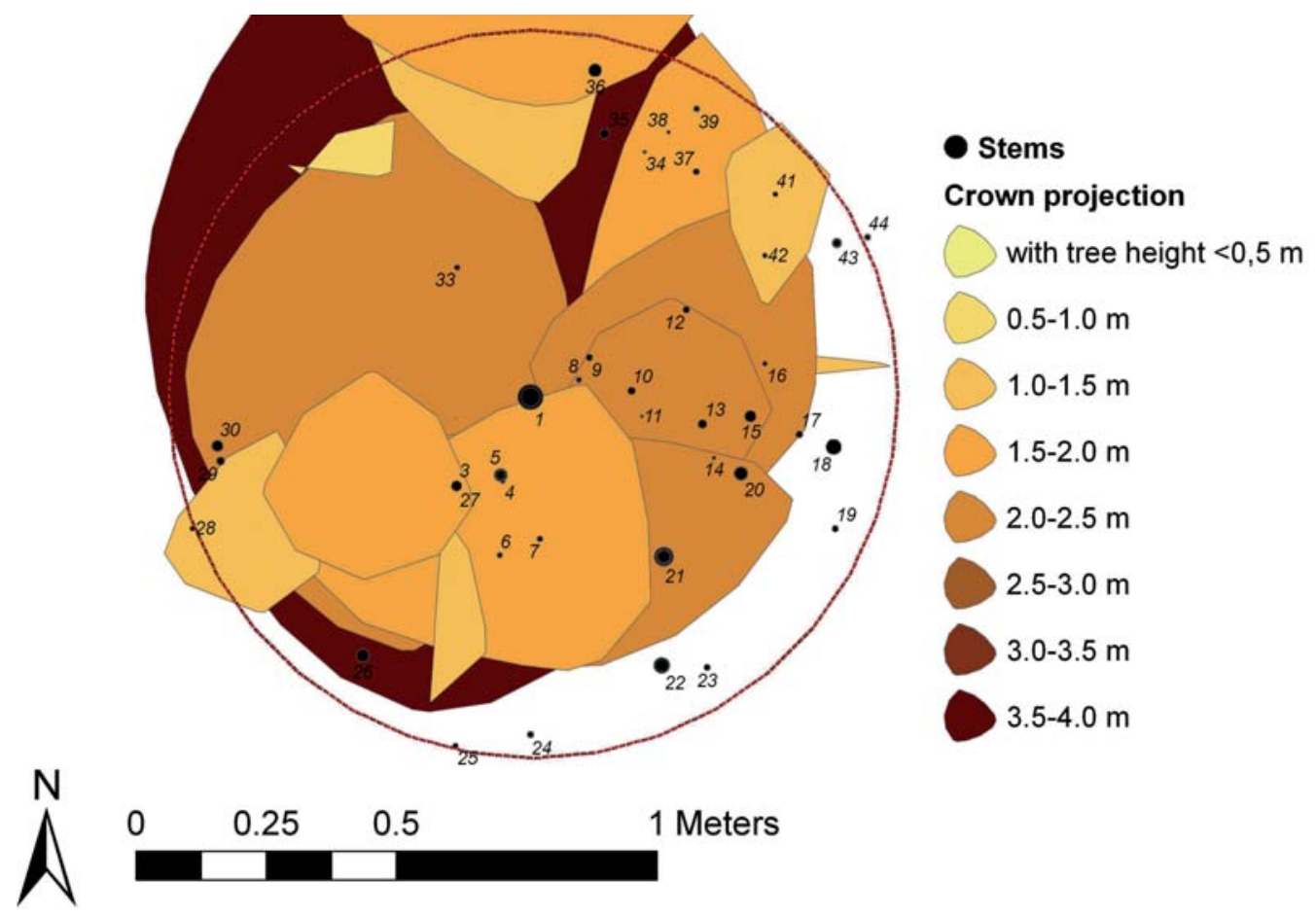

Fig. 5. An example of a circular plot at the Vrchslatina research site (specifically for spruce plot number 3; the sketch shows positions of trees, their diameters, heights and crow projections) 
pieces for every ecosystem. The soil respiration measurement was repeated twice a month for the entire growing season (totaling 12 measurement sessions). In this year, no spruce trees were cut. For the estimation of the current year's needle production, a model (tree height, height increments and length increments on branches of the three upper whorls) was utilized. The model was implemented for trees situated on circular plots which were measured for the aforementioned characteristics (independent variables).

Measurements in the years 2009 - 2012 provided input data for the calculations of above- and belowground biomass standing stocks as well as NPP in the young beech, spruce and grass stands. As well as this, we obtained further information, for example about foliage parameters, seasonal dynamics of height and diameter increments as well as fine root elongation and soil respiratory intensity.

\section{Future of the research site and conclusion}

Our results indicate that growth strategies between the beech and spruce stands differed more in the aboveground than the below-ground compartments. Evidently, young forest stands represented very different ecosystems from grass communities in terms of carbon sequestration and cycling. Clear differences in productivity were also found between the specific years, this indicates significant effects of climatic conditions, mainly temperature or global radiation and precipitations. Important knowledge (not originally planned for in the project proposal) was obtained on how the bio-sociological status of trees can influence morphological features of aboveground compartments and biomass allocation. Hence, we could use some of the results in another ongoing research project entitled "Effect of intra- and inter-specific competition on production ecology in beech and spruce stands" (APVV-0273-11).

So far our measurements have generated results covering growth processes of the beech and spruce over four years and the grass stand over three years. During the years of observation, the research stands experienced varied patterns of climatic features (especially for precipitations), the years were rather contrasting. Specifically, 2009 was very dry, 2010 very moist, and 2011 and 2012 typical with a relatively normal amount of precipitation, but with some drought episodes. We hope to continue our research at the same locality for a further 3-4 years. A long-term study - for almost a decade will allow for the understanding of inter-specific differences in the structure of biomass standing stocks and NPP between diverse types of ecosystems in respect to certain climate conditions. Important conclusions could come from the results concerning proportions of standing stocks and productivity between fast turnover biomass (carbon cycling) and long-term turnover biomass (carbon sequestration).
Since our experiment is at its half-way point, we aim to obtain further interesting results which will throw more light on issues related, not only to the reactions of forests to climate, but also to the role of forests in carbon fluxes and sequestration. Our results could hopefully contribute to a mosaic of findings providing arguments for optimal decision-making on future forest management under changing ecological conditions. We assume that prospective forest management will optimize not only productive functions but also the carbon sequestration capacity of forest stands and their tolerance to climate extremes. Doubtlessly the regulation of tree species' composition of the forest stands might be a principal way to achieve these integrated objectives.

\section{Acknowledgement}

This work was supported by the Slovak Research and Development Agency under the project "Comparative studies on allocation of net primary productivity in beech and spruce stands" (APVV-0268-10) and "Effect of intra- and inter-specific competition on production ecology in beech and spruce stands" (APVV-0273-11). The authors thank Mr. Vojtech Ilčik, MSc. for help with the selection of the research site and Mr. Miroslav Lipnický, Milan Meřuš a Ján Šulko for excellent jobs in the field and laboratory.

\section{References}

Bošela, M., Šebeñ, V., Pajtík, J., KonôPKa, B., Vida, T., 2013: Modelling effects of weather condition on seasonal dynamics of the stem circumference increment in a mixed stand of Norway spruce and European beech. Lesnícky časopis - Forestry Journal, 59(3): 180-188.

Dixon, R.K., Solomon, A.M., Brown, S., Houghton, A.A., Trexier, M.C., Wisniewski, J., 1994: Carbon pools and flux of global forest ecosystems. Science, 263: 185-190.

Helmisaari, H.S., Makkonene, K., Kellomäki, S., Valtonen, E., MälKÖNEN, E., 2002: Below- and above-ground biomass, production and nitrogen use in Scots pine stand in eastern Finland. Forest Ecology and Management, 165: 317-326.

JANSSENS, I.A. et al., 2005: The carbon budget of terrestrial ecosystems at country-scale - a European case study. Biogeosciences, 2: $15-26$

KonÔPKA, B. et al., 2010: Comparative studies on allocation of net primary productivity in beech and spruce stands. Project proposal. $24 \mathrm{p}$.

KonôPKa, B., PAJTík, J., ŠEBeň, V., LuKac, M., 2011: Belowground biomass functions and expansion factors in high elevation Norway spruce. Forestry, An International Journal of Forest Research, 84(2): 41-48.

KonôPKa, B., Pajtík, J., Noguchi, K., LuKac, M., 2013a: Replacing Norway spruce with European beech: A comparison of biomass and net primary production patterns in young stands. Forest Ecology and Management, 302: 185-192.

KonôPKa, B., PAJTíK, J., MaLovÁ, M., 2013b: Fine root standing stock and production in young beech and spruce stands. Lesnícky časopis - Forestry Journal, 59(3): 163-171.

Li, Z., Apps, M.J., BANFIEld, E., KurZ, W.A., 2002: Estimating net primary production of forests in the Canadian Prairie Provinces using as inventory-based carbon budget model. Canadian Journal of Forest Research, 32: 161-169. 
LINDNER et al., 2010: Climate change impacts, adaptive capacity, and vulnerability of European forest ecosystems. Forest Ecology and Management, 259: 698-709.

MÁliš, F., KonôPKA, B., MalovÁ, M., 2013: Post-harvest biomass stock and productivity of Calamagrostis epigejos community under beech and spruce forest stand. Lesnícky časopis - Forestry Journal, 59(3): 197-202.

PAJTík, J., KonôPKa, B., Marušák, R., 2013: Above-ground net primary productivity in young stands of beech and spruce. Lesnícky časopis - Forestry Journal, 59(3): 154-162.
Priwitzer, T., Capuliak, J., Schwarz, M., 2013: Preliminary results of soil respiration in beech, spruce and grassy stands. Lesnícky časopis - Forestry Journal, 59(3): 189-196.

ŠEbeň, V., BoŠEla, M., KonôPKA, B., PAJTíK, J., 2013: Indices of tree competition in dense spruces stand originated from natural regeneration. Lesnícky časopis - Forestry Journal, 59(3): 172-179.

ZúBRIK, M. et al., 2009: Výskum efektívneho využívania environmentálneho, ekonomického a sociálneho potenciálu lesov na Slovensku. Správa pre priebežnú oponentúru úlohy výskumu a vývoja. Zvolen, Národné lesnícke centrum, 159 p.

\section{Photo documentation}

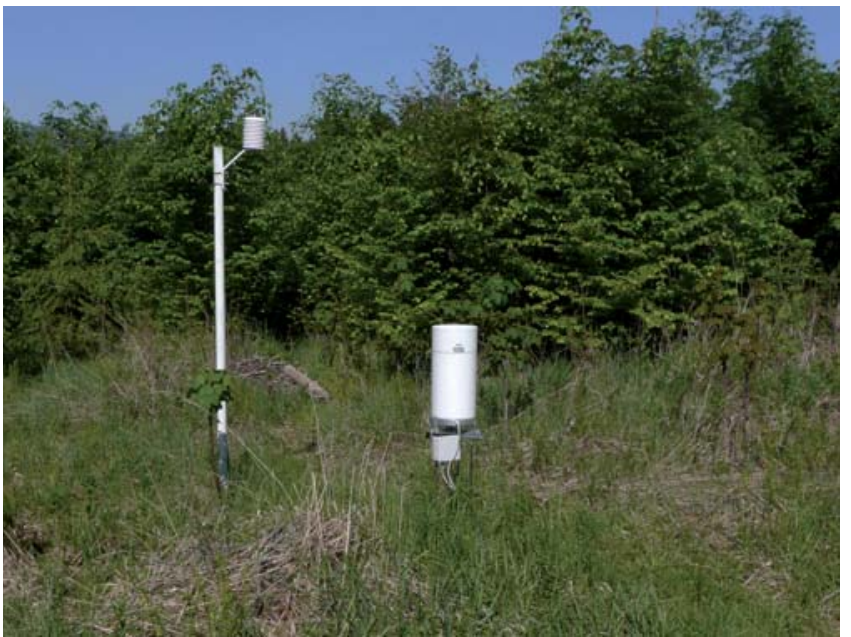

Photo 1. Mini meteo-station at the Vrchslatina research site. Beech stands used for observations are visible in the backgrund. The foreground represents the grass community dominated by Calamagrostis epigejos during early spring

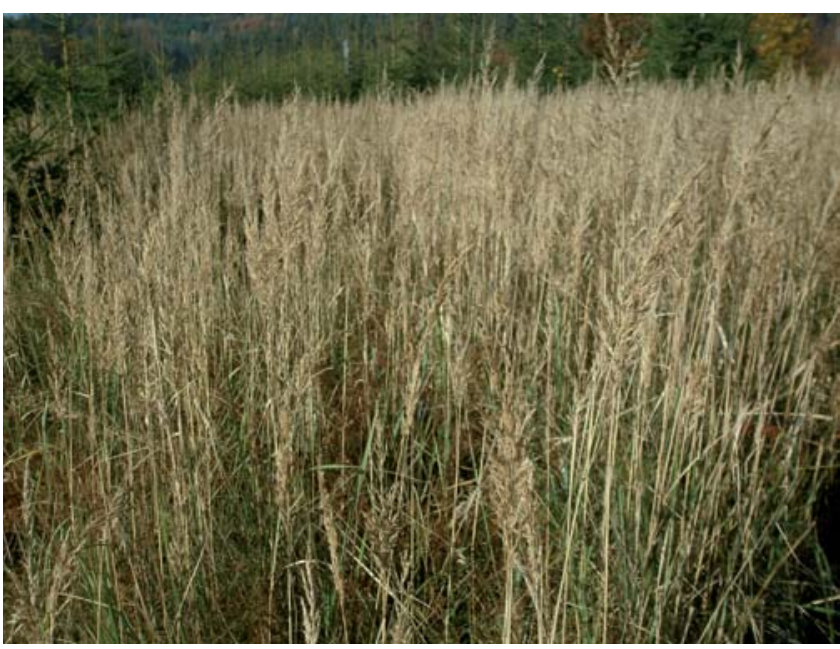

Photo 3. The Calamagrostis epigejos dominating in the grass stand at the Vrchslatina research site

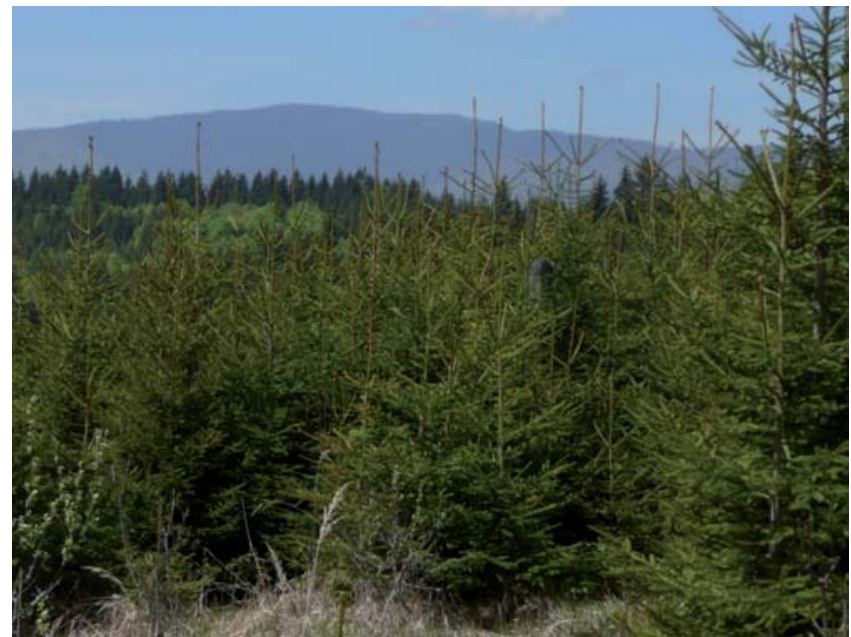

Photo 2. Young spruce stand at the Vrchslatina research site

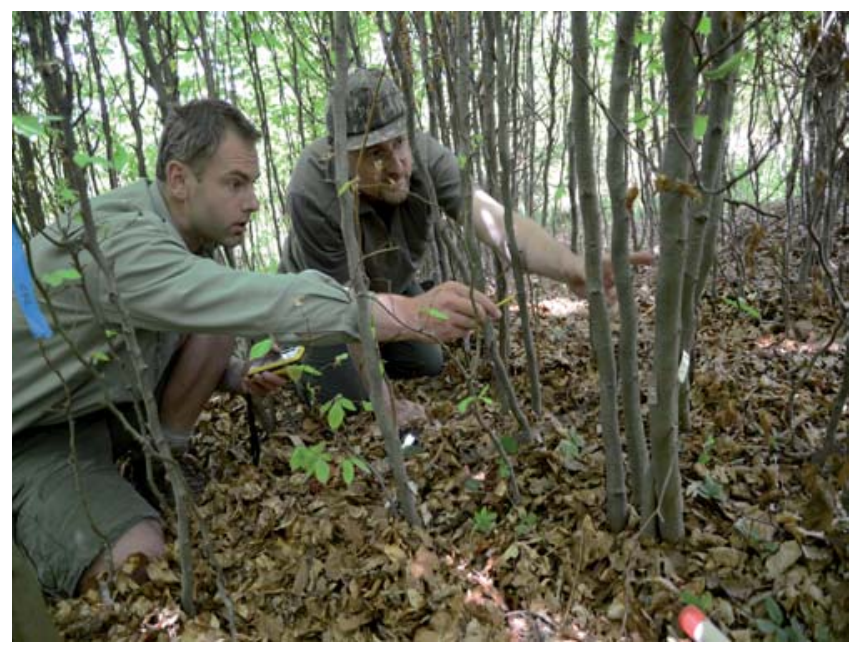

Photo 4. Measuring coordinates of young beech trees in the summer of 2011 


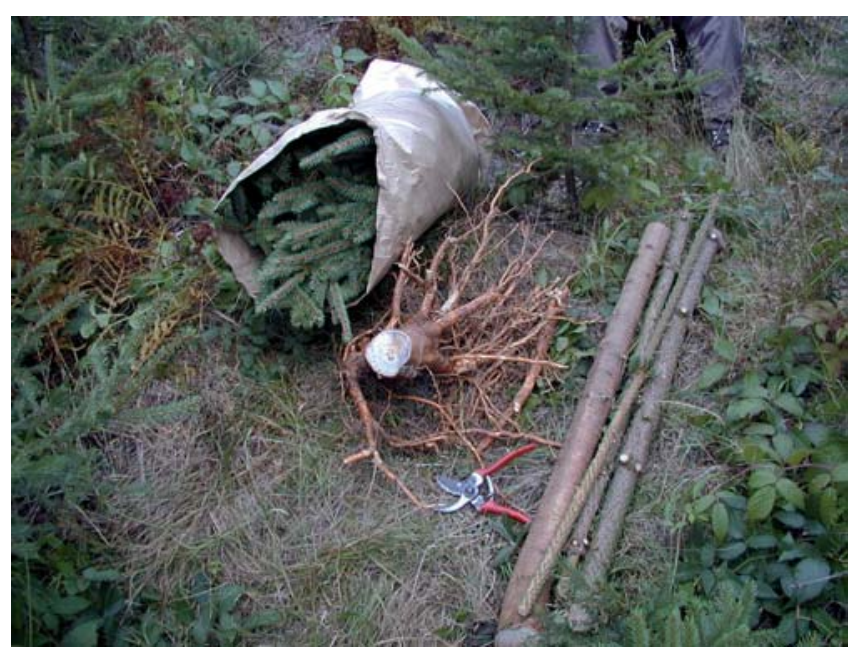

Photo 5. A sample spruce tree divided into main tree compartments (field works performed in 2009)

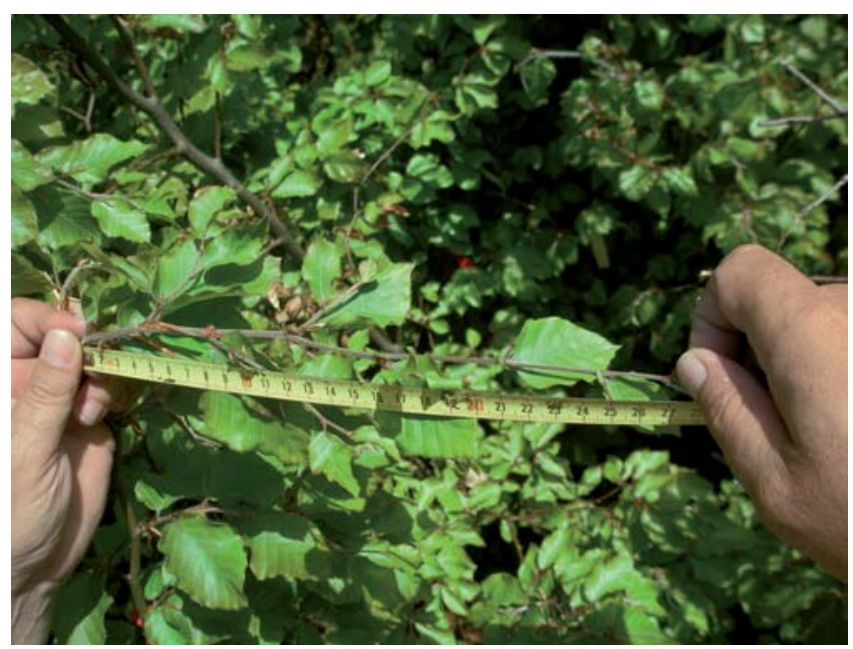

Photo 7. Measuring terminal shoot length increment in beech

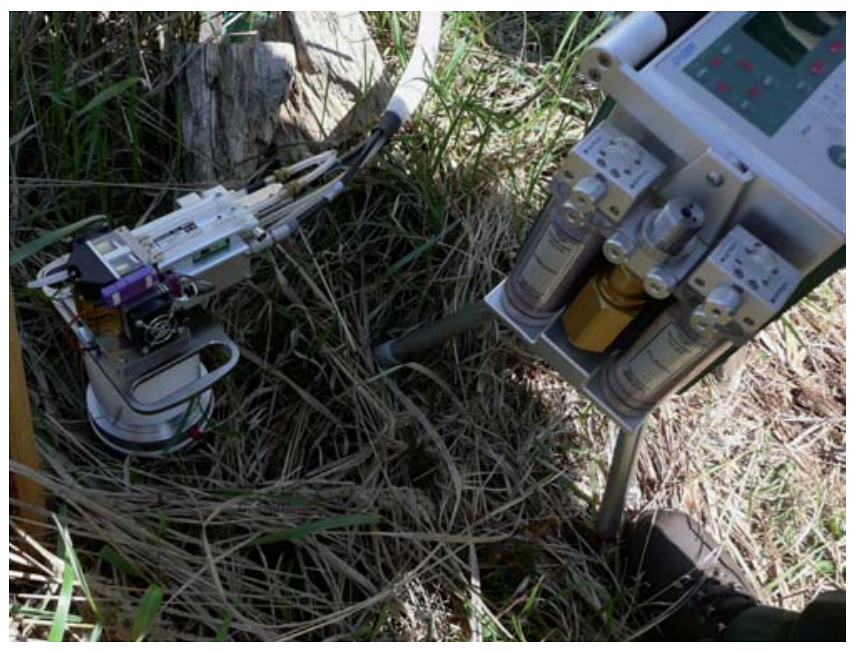

Photo 9. Field measurement of soil respiration in the grassland community

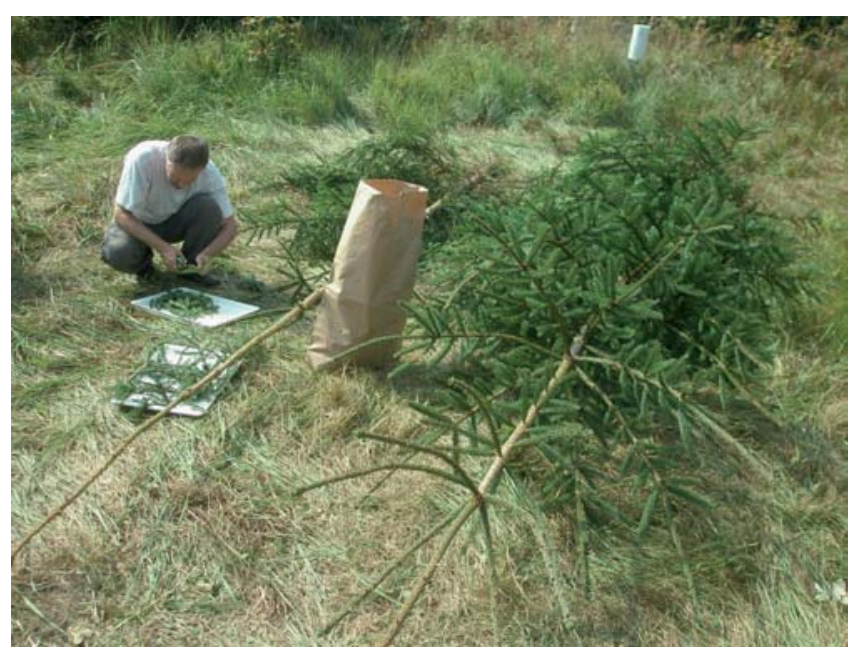

Photo 6. Separation of shoots in the sampled spruces by the year of birth (field works performed in 2011)

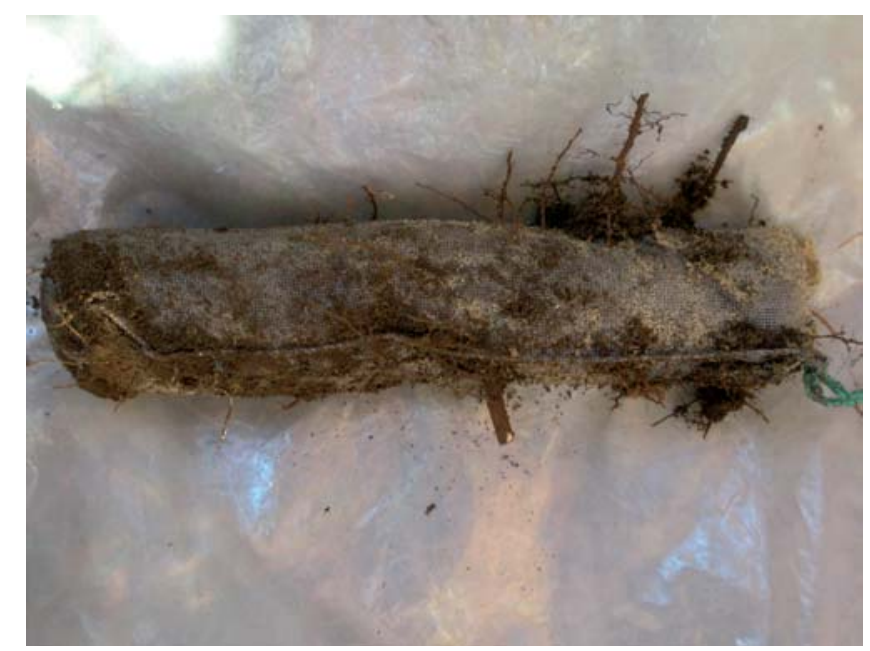

Photo 8. Ingrowth bag harvested after two growing seasons incubation under the beech stand

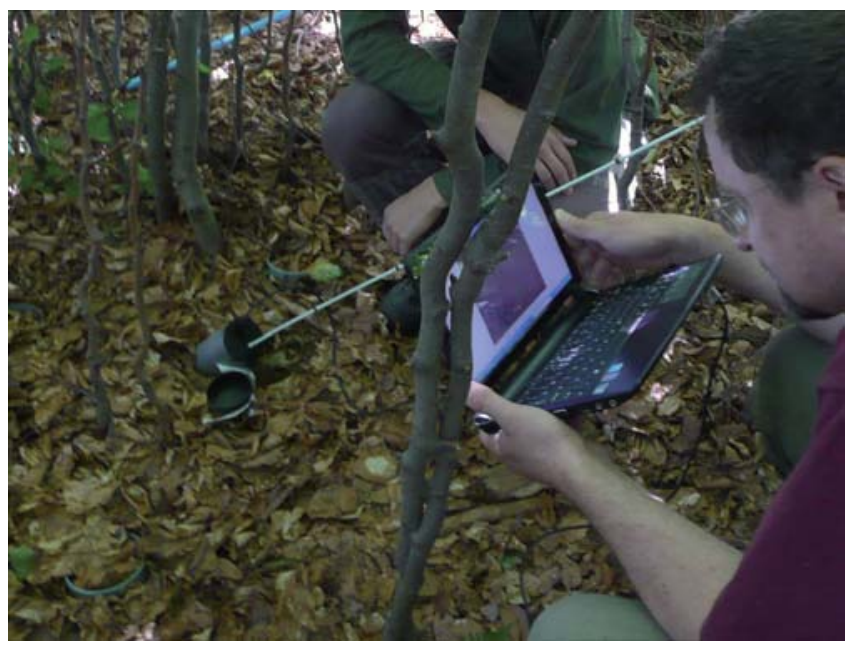

Photo 10. Non-destructive scanning and recording beech roots through transparent tubes 


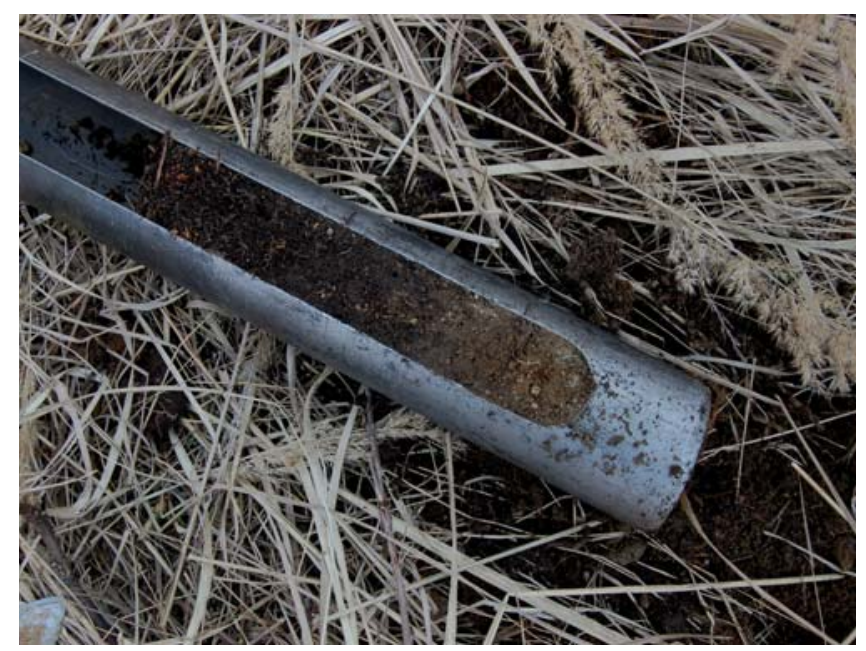

Photo 11. A soil core of the upper 30-cm-layer taken under the grass community

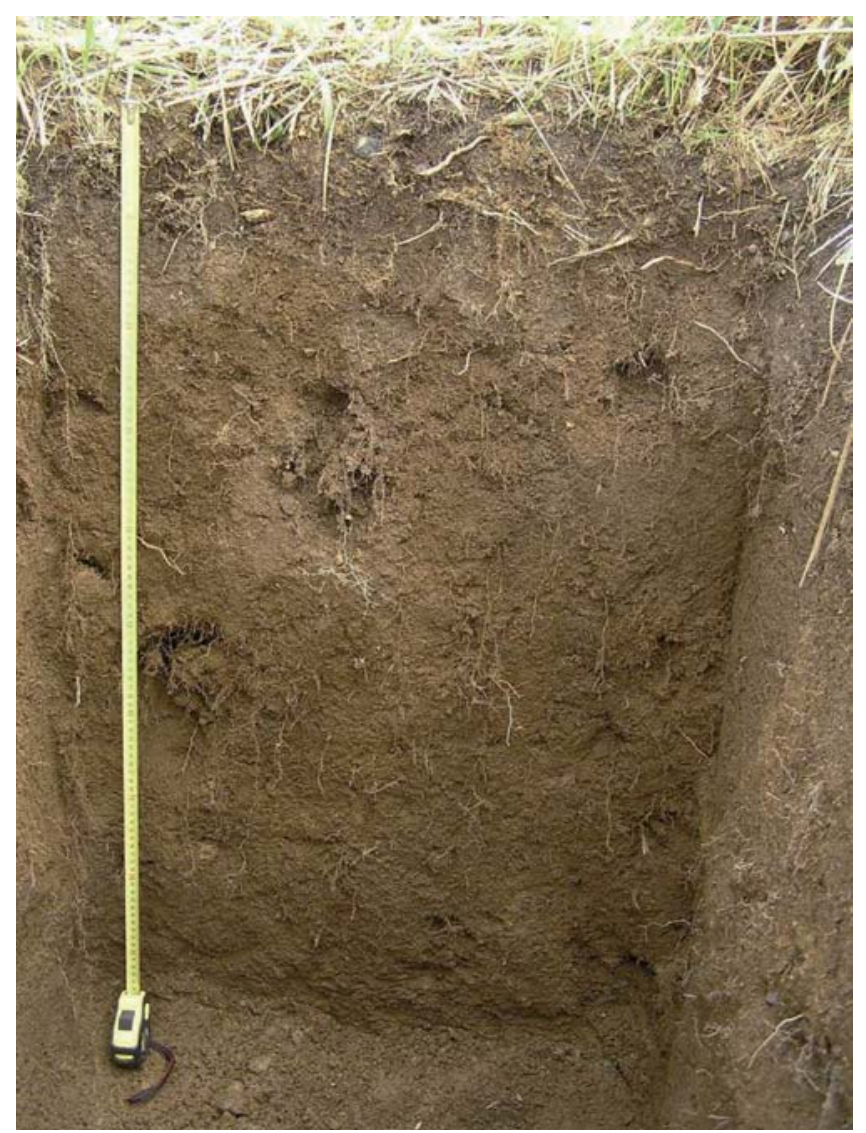

Photo 12. View of the soil profile (depth of $100 \mathrm{~cm}$ ) at the research site. Good soil structure, absence of coarse rock fragments and rather intensive rooting in deeper horizons of soil are visible 